\title{
New molecular approach for the simulation of nanoparticle \\ - polymer interactions: application to the system formed by a lysophospholipidic micelle and polyacrylic acid
}

\author{
YvES CHAPRON - Alpine Institute of Environmental Dynamics - yves.chapron@aied.fr \\ ALAIN PORQUET - Alpine Institute of Environmental Dynamics, SCHEMA \\ MoNTSERRAT FILELLA - SCHEMA, Institute F-A Forel - montserrat.filella@unige.ch \\ Received: 07.04.2010. - Érkezett: 2010.04.07. http://dx.doi.org/10.14382/epitoanyag-jsbcm.2010.19
}

\begin{abstract}
Better understanding of the forces between modified or unmodified nanoparticles would be beneficial for developing new strategies for the production of engineered nanoparticle suspensions, as well as for predicting their fate and transport in the environment. Molecularlevel simulations, such as Molecular Dynamics can be useful for understanding the interactions between colloidal nanoparticles, but simulations of very large systems are constrained by the long calculation times and require enormous computer resources. A new computation approach that combines series of cycles of Rigid Body Dynamics and Molecular Dynamics has been applied to the study of the interaction of a lysophospholipidic micelle with polyacrylic acid. The results obtained show that the method makes it possible to reach a stationary interaction structure quite rapidly. The method is ready to be applied to the study of the interaction of a wide range of nanoparticles of industrial, environmental or biological interest via a widely-used and freelyaccessible computer code.

Keywords: nanoparticle, micelle, polyacrilic acid, lysophospholipidic micelle, rigid body dynamics, molecular dynamics
\end{abstract}

\section{Introduction}

There are currently more than 900 products on the market that contain nanoscale materials, and the development and commercial production of engineered nanoparticles (ENP) is expected to continue to grow rapidly. Many ENP applications (e.g., as composite materials, components of drug delivery agents, etc.) require ENP suspensions that remain stable in polar media such as water or polymeric resins. However, most ENP are strongly hydrophobic and bare ENP minimize their surface free energy by forming settleable aggregates in solution. To prepare uniform, well-dispersed mixtures, the ENP's exterior surface needs to be modified. Two different methods have been used to stabilize colloidal nanoparticles: either incorporation of functional groups through acid treatment or dispersion by surfactant or polymer adsorption. This means that a better appraisal of the forces between modified or unmodified nanoparticles would help to gain a better understanding of the effects of the above mentioned surface modifications and develop new strategies for producing ENP suspensions. Moreover, the aggregation state of ENP also has a strong influence on their fate and transport in the environment. Understanding the factors governing the aggregation behavior of ENP on its own and in contact with natural particles, surfaces and organic macromolecules, is a key to evaluating their environmental transport, fate and potential interaction with biological species.

Historically, the Derjaguin-Landau-Verwey-Overbeek (DLVO) theory has been used to describe electrostatic and van der Waals interactions in colloidal systems [1,2]. However, the
Yves CHAPRON

received his "Doctorat d'Etat ès Sciences Physiques" from the University of Paris in 1970 ( $\sim$ PhD with 2 thesis). Scientist at Atomic Energy Authority (CEA) 1963-1999, former professor at the "Ecole Centrale de Paris" and leader of the Modelisation Biophysics Group at CEA/Grenoble. He worked on nuclear reactor physics, radioprotection, aerothermochemistry, electrochemistry (pioneering in pulse polarography). Later, on biophysics on vision, electrophysiology, pioneering in patch-clamp \& ionic channel of cell membrane. Author of 100 communications (articles), movies and patents. Since 1999 president of the Alpine Institute of Environmental Dynamics (AIED). The AIED is dedicated to the study of the molecular biogeochemistry of waters, soils and materials.

Alain PORQUET

received his PhD in Theoretical and Computational Chemistry from the University of Strasbourg in 1997. After the PhD thesis, he became research associate at the universities of Lausanne and Geneva. He has worked in molecular dynamic simulations of phospholipids bilayers, theoretic calculations of aqua-complexes. He has created a program to generate molecular structures randomly to the study humic substances.

Montserrat FILELLA received her $\mathrm{PhD}$ in Chemistry from the University of Barcelona in 1986. She teaches Environmental Chemistry at the University of Geneva, where she arrived in 1987. Since 2007

she also works in the development of a society specialised on fundamental research in environmental chemistry in Luxembourg. She is an IUPAC fellow and member of a number of scientific societies. Her main research interests focus on the understanding of the physicochemical processes regulating the behaviour of chemical elements in environmental and biological compartments. The three main axes of her research concern the study of: colloids in natural waters, natural organic matter and Group 15 elements.

DLVO theory was originally developped for micron-sized colloidal particles and relies on a continuum approximation that may not extend to nanosized objects. Existing opinions on this issue are contradictory up to this point. On the one hand, results from studies where the functional dependence of the aggregation rates on electrolyte concentration has been measured show that the behavior of nanoparticles follows the qualitative predictions of the DLVO theory in regard to the effect of counterion concentration and valence [3-13]. However, experiments in the literature show that DLVO theory does not always work for micrometer-scale particles at close separations [14-16] and modeling studies indicate that the classical theory might have less predictive power for nanocolloids of less than $10 \mathrm{~nm}$ in diameter than for larger particles. For instance, according to Fichthorn and Qin [17, 18], forces that are not taken into account by DLVO theory, such as solvation and depletion, could be very important in colloidal nanoparticle systems.

Molecular-level simulations, such as molecular dynamics (MD), can be useful in understanding the interactions between colloidal nanoparticles. These studies can yield atomicscale detail and they can be used to resolve the origins and magnitudes of forces between those particles. However, MD simulations on very large systems, such as the ones formed by 
several interacting nanoparticles, require very large computer resources which make them prohibitive, even with the current calculation capabilities. To overcome this limitation, we have tested a new strategy that combines series of cycles of Rigid Body Dynamics (RBD) and MD. Its application to the study of the interaction of a lysophospholipidic micelle (LPE) with polyacrylic acid (PAA) is presented here. The same system constructed with explicit water in a parallelepiped box of minimum size would contain more than 120,000 atoms, implying very long calculation times (i.e., when the number of atoms increases in a system, as a consequence, a quadratical increase in the calculation time is observed). The substances used in this study have been chosen only as model compounds with the only objective being to test the new calculation strategy. However, they were not chosen arbitrarily. DLPE is involved in many aspects of living processes [19] and, recently, phospholipid micelles have been used, among other amphilic polymers, to encapsulate hydrophobic quantum dot nanoparticles to create water soluble materials suitable for biological applications [20, 21]. Polyacrylic acid (PAA) has been very often chosen as a polymer and polyelectrolyte model substance. A number of industrial processes rely on the use of polyelectrolytes to provoke the flocculation and/or the dispersion of colloidal particles and, in the past decades, the importance of polymer-colloid interaction has also been widely recognized in soil aggregation and pollutant transport in natural waters.

\section{Methods}

\subsection{Computational methods}

\subsubsection{Molecular Dynamics simulations}

In $\mathrm{MD}$, the Newtonian equations of motion are integrated to make it possible to follow the displacement of particles over a certain period of time. This procedure allows the phase space to be sampled and produces a physical dynamic trajectory that permits temporal analysis. MD simulations were performed using the following representation of potential energy:

$E_{\text {total }}=\sum_{\text {bonds }} K_{r}\left(r-r_{\text {eq }}\right)^{2}+\sum_{\text {angles }} K_{\theta}\left(\theta-\theta_{\text {eq }}\right)^{2}+\sum_{\text {dinearals }} \frac{V_{n}}{2}[1+\cos (n \phi-\gamma)]+\sum_{\text {nonbonded }}\left[\frac{B_{i j}}{R_{i j}^{12}}-\frac{A_{i j}}{R_{i j}^{6}}+\frac{q_{i} q_{j}}{\varepsilon R_{i j}}\right]$

where (i) bond stretching and valence angle deformation are represented by an harmonic potential where $K_{\mathrm{r}}$ and $K_{\theta}$ are the constant forces and $r_{\text {eq }}$ and $\theta_{\text {eq }}$ are reference values; (ii) a torsional term, defined by a set of $V_{\mathrm{n}}, n$ and $\gamma$ parameters, is associated with the dihedral angles; (iii) the non-bonded interactions are split up into Van der Waals interactions, represented by a Lennard-Jones potential defined by parameters $A_{\mathrm{ij}}$ and $B_{i j}$, and electrostatic interactions modelled by a Coulombic potential. Electrostatic and van der Waals interactions are only calculated between atoms in different molecules or for atoms in the same molecule separated by at least three bonds. MD calculations have been performed using XPLOR $[22,23]$. The united-atoms (UA) approach has been used in the calculations. UA force fields for $\mathrm{MD}$ simulations provide a higher computational efficiency with little sacrifice in accuracy when compared to all-atom force fields, especially in aliphatic chain simulations where very few specific interactions exist [24].

\subsubsection{Rigid Body simulations}

Rigid Body (RB) dynamics solves Newton equations of motion for rigid collections of atoms. Atoms are grouped into rigid groups, the motion of which is determined by summing the forces acting on all elements of a group and integrating the $\mathrm{RB}$ equations of motion. The XPLOR implementation of $\mathrm{RB}$ dynamics follows the algorithm described by HeadGordon and Brooks [25]. This algorithm treats each group as a continuous mass dislocated at the center-of-mass position and characterized by its inertia tensor. Only the non-bonded interactions are computed as RB dynamics energy interactions. However, all atoms are taken into account for the calculation of the general energy. The theoretical details are can be found in the XPLOR manual ([22], pages 136-140).

\subsection{Choice of the polymer and micelle models}

Polyacrylic acid (PAA) monomers were simulated using a united-atom (UA) approach. Other parameters needed for the UA model were the standard parameters proposed by the Charmm/XPLOR force field for united atoms [27]. Table 1. shows the atomic charges of the protoned PAA polymer chains used in the MD simulations.

The lysophosphatidylethanolamine (LPE) monomer was derived from the crystal structure of dilaurylphosphatidylethanolamine (DLPE) [28] by replacing the fatty acid substituent of the central glycerol oxygen with a hydroxyl group. Atomic charges were computed with semi-empirical quantum chemistry [26]. They are shown in Figure 1. The Kerubin program [29] was used to build the micelle from the LPE monomers.

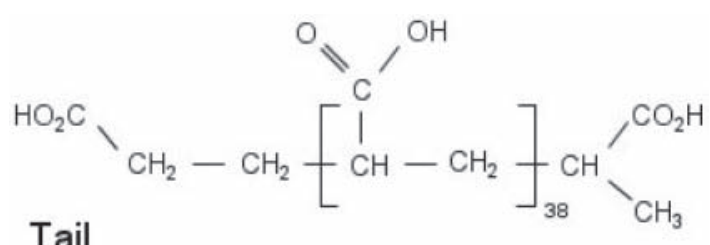

Tail

Head

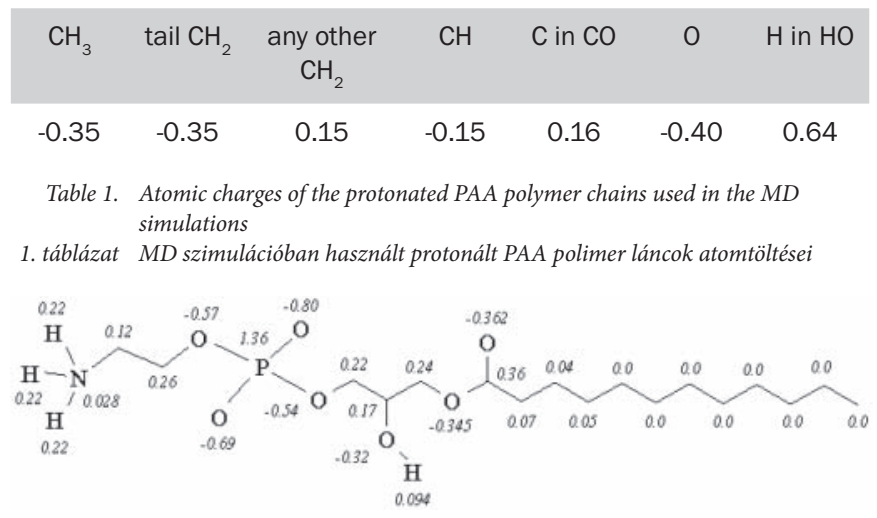

Fig. 1. Formula and atomic charges of the lysophosphatidylethanolamine (LPE) monomers used in the MD simulations

1. ábra AzMD szimulációkban vizsgált lizofatidil-etanolamin (LPE) monomerek összegképlete és atomtöltései 


\section{Results and discussion}

A PAA polymer chain of 40 monomers (330 atoms), all with trans-conformation, was used to create the initial structure of the complex. This polymer chain was immerged in a periodic box of 6516 water molecules $(\varepsilon=1)$ and simulated by MD with XPLOR using the UA model for $10 \mathrm{ps}$. The water molecules of the first hydration shell of the polymer chain (258 water molecules) were kept for later in the simulation of the interaction between the polymer and the micelle.

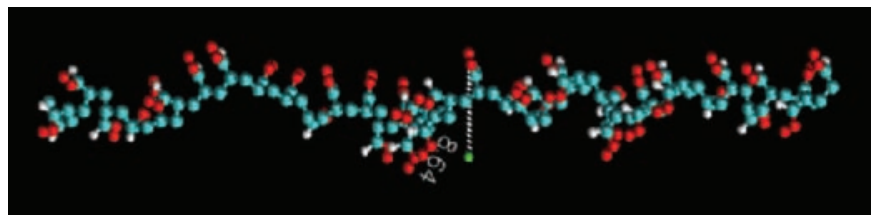

(a)

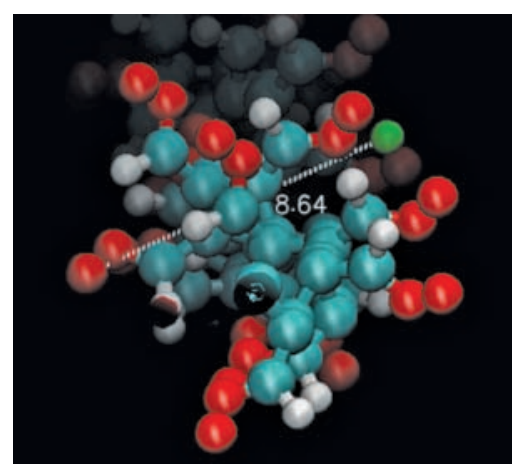

(b)

Fig. 2. Longitudinal (a) and cross-section (b) snapshots of the hydrated polyacrylic acid (PAA) polymer build with 40 monomers

2. ábra A 40 monomerböl álló hidratált poliakril sav hosszmenti (a) és keresztmetszeti (b) képe

Figure 2. shows snapshots of the hydrated PAA polymer. The simulated PAA has the following dimensions: mean diameter $\sim 8$-9 $\AA$, hydrated mean diameter $=33 \AA$, length $=78.6 \AA$, hydrated length $=105 \AA$.

A non-charged and equilibrated micelle composed of 56 LPE monomers (2441 atoms) was built with the Kerubin program. The cohesion of the micellar structures is partly due to the interactions between the polar heads of the phospholipid chains of the micelle and water molecules in the first hydration shells. Thus the introduction of explicit water molecules $(\varepsilon$ $=1$ ) around the micelles is crucial in order to maintain this cohesion during the MD simulations. For this reason, the LPE micelle was equilibrated by 0.1 ps of MD simulation in a spherical box of 2784 water molecules without periodicity. Only 2441 water molecules were kept to hydrate the micelle in further simulations.

Figure 3. shows snapshots of different steps in the process of building the LPE micelle. The simulated micelle has the following dimensions: mean diameter (from opposite $\mathrm{N}$ atoms) $=53 \AA$, hydrated mean diameter (from opposite $\mathrm{N}$ atoms) $=62 \AA$. Slightly lower diameters are obtained if the distance from opposite $\mathrm{P}$ atoms is measured instead. In this case, mean diameter $=50 \AA$, hydrated mean diameter $=61 \AA$.

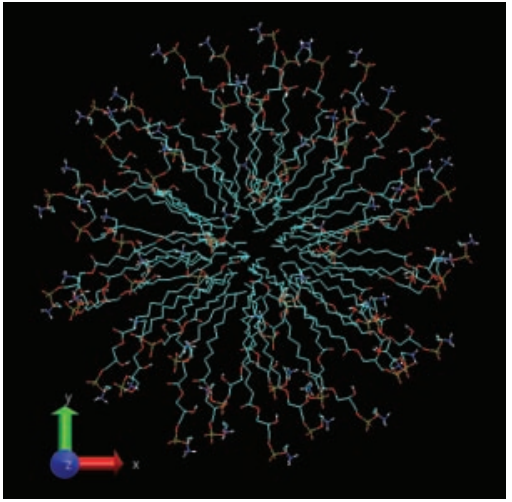

(a)

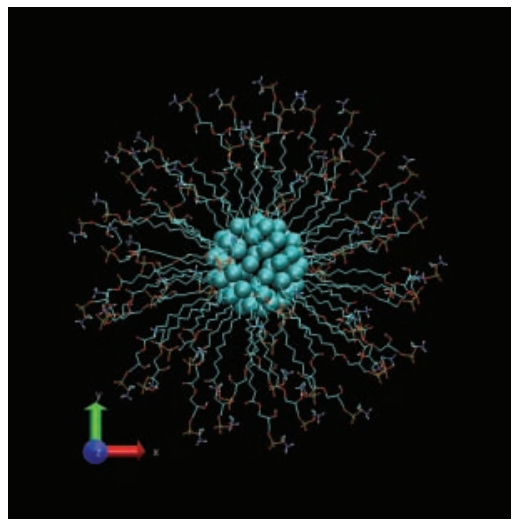

(b)

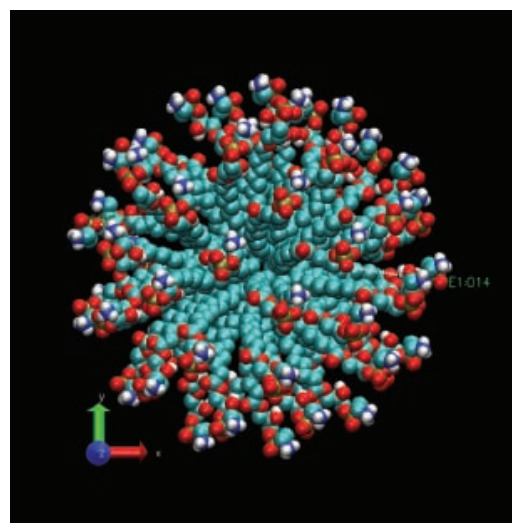

(c)

Fig. 3. Snapshots showing different steps in the process of building the LPE micelle: (a) first micelle built up with Kerubin, (b) first minimisation of the LPE, (c) micelle

3. ábra Az LPE micella felépülésének különbözö lépéseit bemutató képek (a) az elsö micella felépülése Kerubin-nel, (b) az LPE elsö minimalizálódása, (c) a micella

For the RB simulation, two groups of atoms were defined: the hydrated micelle and the hydrated polymer chain. The polymer chain-micelle system included 10011 atoms. To equilibrate the system, the procedure alternated between RB simulation phases, to displace the micelle relatively to the polymer chain $\left(\varepsilon_{\text {water }}=80\right)$, and MD simulation phases, to re-equilibrate the water molecules. In order to reduce calculation times, all the atoms of the micelle and of the polymer chain are frozen during each MD phase without modifying the positions of the 'dry' parts of each rigid body obtained in the previous RBD cycle. 
Different time step values were tested with two temperature coupling modes [30]. The Langevin method was opted for, since the Berendsen coupling method induced too many temperature fluctuations. Integration times ranging from 1 to $15 \mathrm{fs}$ were tested using this method, and an optimum integration time of 5 fs was finally chosen. The alternating RB/MD cycles lasted for $10 \mathrm{ps}$ and included four successive series of $2.5 \mathrm{ps} \mathrm{RB}$ and $50 \mathrm{fs} \mathrm{MD}$ with an integration step of $1 \mathrm{fs}$. Figure $4 a$ shows temperature fluctuations with a Langevin thermal bath $(\beta=30$, $\mathrm{T}=300 \mathrm{~K}$ ), RBD only. Temperature fluctuations during four successive cycles of RBD and MD calculations are shown in Figure $4 b$; they reflect water reorganisation needed during the short MD runs.

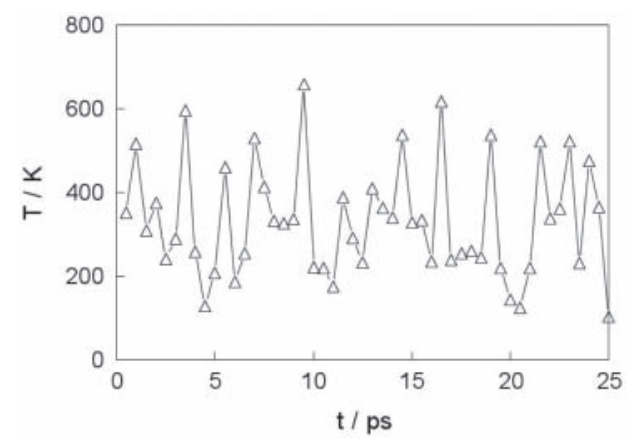

(a)

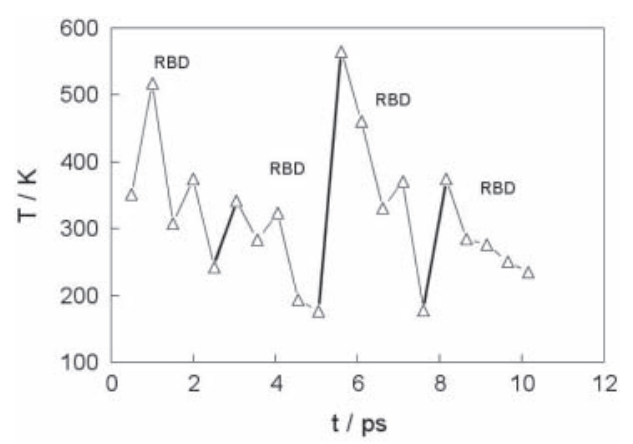

(b)

Fig. 4. (a) Temperature fluctuations with a Langevin thermal bath $(\beta=30, T=300$ $K) R B D$ only. (b) Temperature fluctuations during four successive cycles of $R B D$ and $M D$ calculations

4. ábra (a) Hömérsékletingadozások a Langevin höfürdöben $(\beta=30, T=300 \mathrm{~K})$ csak RGB-vel számolva, (b) Hömérsékletingadozások RBD és MD módszerek kombinációjával számolva, négy egymást követó ciklusban

Quick equilibration of the interaction energies was observed by using the RB/MD method. Figure 5. shows the evolution of the non-bonded interaction energies, van der Waals and electrostatic, between the LPE micelle and the PAA polymer chain during four mixing $\mathrm{RBD}$ and MD cycles. The initial repulsion, resulting from the arbitrary initial position of the two objects, evolves quite rapidly to a thermodynamic stabilisation. The MD trajectory Van der Waals energy decreases from +2500 to $-1000 \mathrm{kcal}^{\mathrm{mol}}{ }^{-1}$ thus showing good contact reorganisation of the system configuration. Simultaneously, the MD trajectory electrostatic energy relaxes from an initial value of $-500 \mathrm{kcal}$. $\mathrm{mol}^{-1}$ to a more equilibrated value of $-100 \mathrm{kcal}^{\mathrm{mol}}{ }^{-1}$. The evolution of the non-bonded atomic interactions and the temperature fluctuations during the simulations clearly shows that water reorganised itself during MD phases (50 fs).

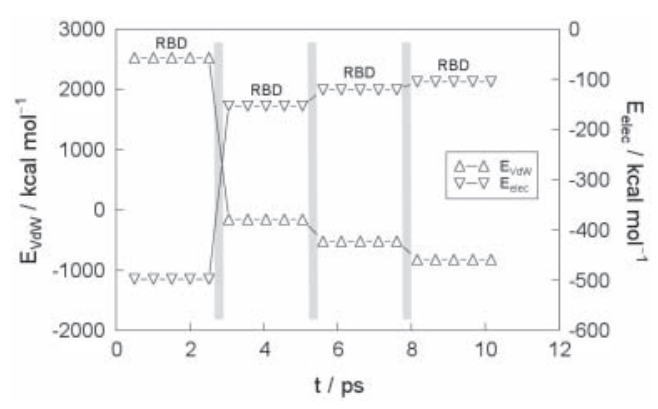

(a)

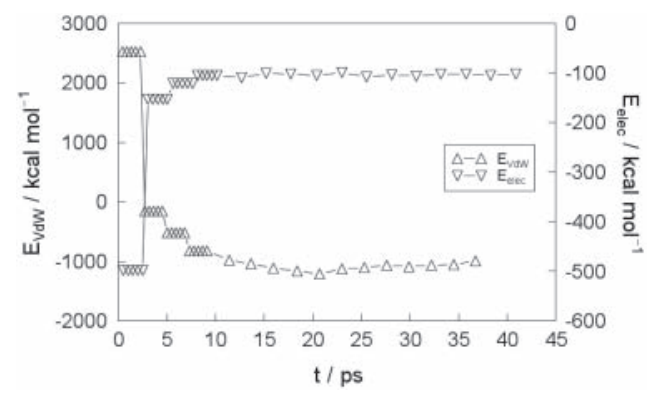

(b)

Fig. 5. Evolution with time of the non-bonded interaction energies between the LPE micelle and the PAA polymer chain during (a) the initial four successive cycles of RBD and MD calculations, (b) the complete simulation (40 ps) van der Waals interactions: $\Delta$; electrostatic interactions: $\nabla . R B D(2.5 \mathrm{ps})$ and $M D(50$ $\left.f_{s}\right)$ steps are clearly indicated in (a)

5. ábra Az LPE micella és a PAA polimer közötti nem-kötö kölcsönhatások energiájának időbeli alakulása (a) az RBD és MD módszerek kombinációjával számolva, az elsö négy egymást követö ciklusban, (b) a van der Waals kölcsönhatások teljes szimulációja (40 ps), $\Delta$; elektrosztatikus kölcsönhatások, $\nabla$. RBD (2,5 ps) és $M D(50$ fs) lépések jól láthatók az (a) ábrán

The evolution of the distances from the head and the tail of the PAA monomer to the LPE micelle center is shown in Figure 6. Interestingly, the head and the tail of the PAA position themselves at a similar distance from the micelle center at the end of the equilibration. Figure 7. shows the evolution of the angles PAA head - micelle - tail PAA (larger angle) and the one formed by two oxygen atoms of the residue 10 of the PAA with the micelle (smaller angle). A correlation between the two angles is observed, as if the micelle rolling over the polymer perturbated them. Finally, a split snapshot of the initial structure of the PAA polymer chain - LPE micelle complex is shown in Figure 8.

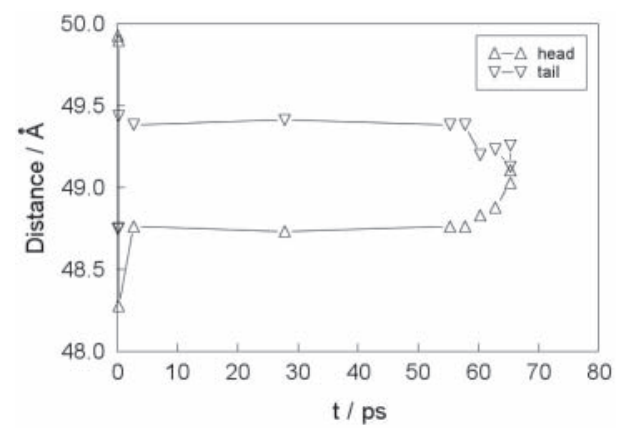

Fig. 6. Evolution with time of the distances from the head $(\Delta)$ and the tail $(\nabla)$ of the PAA polymer chain to the LPE micelle center during four successive cycles of $R B D$ and $M D$ calculations

6. ábra LPE micella középpontja és a PAA polimer lánc fej $(\Delta)$, illetve oldal $(\nabla)$ része közötti távoság változása az idő függvényében az RBD és MD számitások négy egymást követö ciklusában 


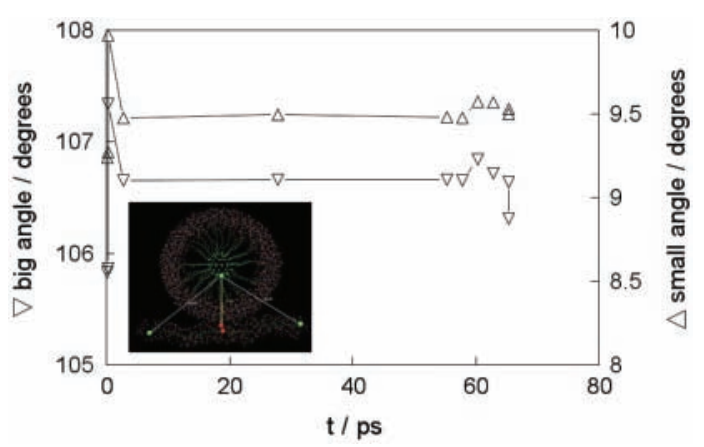

Fig. 7. Evolution of the angles formed by head of the PAA - micelle - tail PAA (big angle) and the OX10 PAA - micelle - OY10 PAA (small angle)

7. ábra A PAA fejrésze - micella - PAA oldalrésze közötti szög (nagy szög) és az OX10 PAA - micella - OY10 PAA közötti szög (kis szög) alakulása

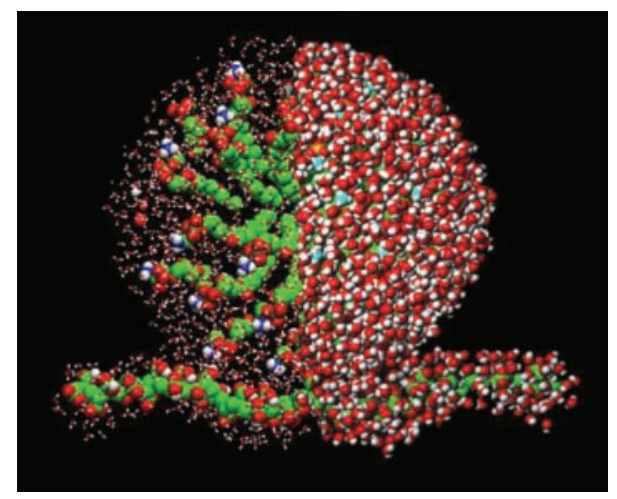

Fig. 8. Snapshot of the initial structure of the PAA polymer chain-LPE micelle complex. At the left hand-side the water molecules are represented in wireframe to clearly show the polymer chain and the micelle monomers. At the right hand-side the water molecules are represented in CPK to show the hydration shell

8. ábra A PAA polimer lánc-LPE micella komplex kezdeti szerkezetének képe. A bal oldalon a vizmolekulákat drótvázzal ábrázoltuk azért, hogy a polimer lánc és a micella monomerek jól láthatók legyenek. A jobb oldalon a vízmolekulák CPK-ban láthatók a hidratációs burok bemutatására

In the procedure explained above, the $\varepsilon_{\text {water }}$ was kept at 80 , so that the electrostatic energy was screened and a reduced number of water molecules moved simultaneously during the MD steps. This procedure has no effect on the van der Waals energies. Once the dynamic equilibrium was reached, water was allowed to reorganise by performing some calculation cycles with implicit water in all the space for RBD and explicit water $\left(\varepsilon_{\text {water }}=1\right)$ for MD. Since the initial position was not far from the final one, spatial and energetic convergences were very rapid. Kinetic parameters associated with such quick processes are not accessible experimentally, but are easy to determine from the results obtained. In the study system, a half time of about 3 ps was calculated. The effect of the sampling cut-off on the final result was also tested and the smallest value $(19 \AA)$ for which results were not affected by the choice was used.

The Constraint Interaction Energy (CIE) and the distance between the two objects were computed at the end of the simulation. The corresponding value of the van der Waals energy (of CIE) between the PAA polymer chain and the LPE micelle $\left(-10.9 \mathrm{kcal}^{\mathrm{mol}}{ }^{-1}\right)$ and the distance between the two objects obtained from this calculation $(10.6 \AA)$ can be used to estimate the value of the Hamaker constant [31]. The socalled Hamaker-De Boer theory is often used to compute van der Waals interactions between macrobodies. This theory is an approximate treatment in which the total attraction energy is obtained by pair-wise summation of London-Van der Waals energies between all molecules of the interacting bodies. Retardation is disregarded. A detailed description as well as a discussion of its limitations can be found in Lyklema [32].

Van der Waals energies and the corresponding Hamaker constants have been computed in the Hamaker-De Boer approximation for a host of geometries but expressions for many geometries are still not well-established. The system being studied can be approximated by the expression for the interaction of a sphere with an infinite plane [32]:

$E_{v d W}=-\frac{A_{H}}{6}\left[\frac{r_{s}}{h}+\frac{r_{s}}{h+2 r_{s}}+\ln \left(\frac{h}{h+2 r_{s}}\right)\right]$

where: $E_{v d W}$ is the van der Waals energy $(J), A_{H}$ is the Hamaker constant $(J), r_{s}$ the radius of the micelle $(\AA)$ and $h$ the minimum distance between the micelle and the polymer $(\AA)$. This gives a value of $4.0 \times 10^{-19} \mathrm{~J}$ for the Hamaker constant. However, according to [33], this approximation can only be applied if the ratio between the distance $h$ and the radius of the sphere $r_{s}$ is $\leq 1$ ( 0.4 in our case) and the ratio of the cylinder radius to the sphere radius is larger than 10 , regardless of the ratio of the cylinder length to its radius. The second condition is not fulfilled in our case. Thus, the value calculated here for the Hamaker constant can only be considered to be an approximation. The value obtained is close, but slightly higher, than the range of values reported for protein-protein interactions in water $\left(1.0 \times 10^{-20}-3.6 \times 10^{-20} \mathrm{~J}\right)[34-40]$. It should be mentioned that Rosenfeld and Wasan [41] have put forward an expression for the interaction between a finite cylinder and a sphere. However, we found an error in relation to the integration domain of their expression when we tried to implement it in Mathcad. Since the objective of this study was to show the capabilities of the modeling approach rather than to calculate an accurate value of the Hamaker constant for the given model system, no further effort was devoted to correcting the equation.

\section{Conclusions}

The results obtained show that the combination of RBD and MD in an explicitly partially hydrated system is a powerful tool for studying interactions between heterogeneous systems because they make it possible to perform complex calculations while keeping calculation times reasonable. It should be pointed out that the same system constructed with explicit water in a parallelepiped box of minimum size contains more than 120,000 atoms. Although it can be solved by using computer codes such as XPLOR [22, 23], VMD [42] and NAMD [43], the high number of atoms present makes the calculation long and the calculation procedure cumbersome because it requires files of structures and atom coordinates be written in hexadecimal notation and the calculation be run by using it.

\section{Acknowledgements}

We are grateful to Eric Desrues for sharing his mathematical insight with us. His help in analysing the expression proposed by Rosenfeld and Wasan was invaluable. 


\section{References}

[1] B. V. Derjaguin - L. Landau: Acta Physicochimica USSR 14 (1941) 633662.

[2] E. J. Verwey - J. T. G. Overbeek: Theory of the Stability of Lyophobic Colloids, Elsevier, New York, 1948.

[3] K. L. Chen - M. Elimelech: Langmuir 22 (2006) 10994-11001.

[4] K. L. Chen - S. E. Mylon - M. Elimelech: Environ. Sci. Technol. 40 (2006) 1516-1523.

[5] K. L. Chen - M. Elimelech: J. Colloid Interface Sci. 309 (2007) 126-134.

[6] K. L. Chen - S. E. Mylon - M. Elimelech: Langmuir 23 (2007) 59205928.

[7] T. Phenrat - N. Saleh - K. Sirk - R. D. Tilton - G. V. Lowry: Environ. Sci. Technol. 41 (2007) 284-290.

[8] K. L. Chen - M. Elimelech: Environ. Sci. Technol. 42 (2008) 7607-7614.

[9] Y. T. He - J. Wan - T. J. Tokunaga: Nanopart. Res. 10 (2008) 321-332.

[10] N. B. Saleh - L. D. Pfefferle - M. Elimelech: Environ. Sci. Technol. 42 (2008) 7963-7969.

[11] T. C. Preston - M. Nuruzzaman - N. D. Jones - S. Mittler: J. Phys. Chem. 113 (2009) 14236-14244.

[12] B. Smith - K. Wepasnick - K. E. Schrote - A. R. Bertele - W. P. Ball - C. O'Melia - D. H. Fairbrother: Environ. Sci. Technol. 43 (2009) 819-825.

[13] D. Velegol - G. L. Holtzer - A. F. Radovic-Moreno - J. D. Cuppett: Langmuir 23 (2009) 1275-1280.

[14] D. Velegol - J. L. Anderson - S. Garoff: Langmuir 12 (1996) 4103-4110.

[15] S. H. Behrens - M. Borkovec - P. Schurtenberger: Langmuir 14 (1998) 1951-1954.

[16] D. Velegol - P. K. Thwar: Langmuir 17 (2001) 7687-7693.

[17] K. A. Fichthorn - Y. Qin: In: Nanotechnology and the Environment: Applications and Implications. Eds. B. Karn, T. Masciangioli, W.-x. Zhang, V. Colvin, P. Alivisatos, ACS Symposium Series 890, chapter 15 (2005), pp. $128-132$.

[18] K. A. Fichthorn - Y. Qin: Ind. Eng. Chem. Res. 45 (2006) 5477-5481.

[19] J. J. Wendoloski - S. J. Kimatian - C. E. Schutt - F. R. Salemme: Science 243 (1989) 636-638.

[20] B. Dubertret - P. Skourides - D. J. Norris - V. Noireaux - A. H. Brivanlou - A. Libchaber: Science 298 (2002) 1759-1762.

[21] X. Michalet - F. F. Pinaud - L. A. Bentolila - J. M. Tsay - S. Doose - J. J. Li - G. Sundaresan - A. M. Wu - S. S. Gambhir - S. Weiss: Science 307 (2005) 538-544.

[22] A. T. Brünger: XPLOR Version 3.1. A System for X-ray Crystallography and $N M R$, Yale Univesity Press, New Haven, 1993.

[23] C. D. Schwieters - J. J. Kuszewski - N. Tjandra - G. M. Clore: J. Magn. Res. 160 (2003) 66-74.

[24] L. D. Schuler - W.F. van Gunsteren: Molecular Simulation 25 (2000) 301319.

[25] T. Head-Gordon - C. L. Brooks: Biopolymers 31 (1991) 77-100.

[26] J.-P. Duneau - S. Crouzy - N. Garnier - Y. Chapron - M. Genest: Biophys. Chem. 76 (1999) 35-53.

[27] B. R. Brooks - R. E. Bruccoleri - B. D. Olafson - D. J. States - S. Swaminathan - M. Karplus: J. Comp. Chem. 4 (1983) 187-217.

[28] M. Elder - P. Hitchcock - R. Mason - G. G. Shipley: Proc. R. Soc. London A (Math. Phys. Sci.) 354 (1977) 157-170.

[29] A. Porquet: Kerubin 4.5, 2002; http://perso.wanadoo.fr/kerubin/.

[30] H. J. C. Berendsen - J. P. M. Postma - N. F. van Gunsteren - A. A. DiNola - J.R. Haak: J. Chem. Phys. 81 (1984) 3684-3690.

[31] H. C. Hamaker: Physica IV 10 (1937) 1058-1072.

[32] J. Lyklema: Fundamentals of Interface and Colloid Science. Volume I: Fundamentals. Academic Press, London, 1991.

[33] Y. Gu - D. Li: J. Coll. Interface Sci. 127 (1999) 60-69.

[34] W. Eberstein - Y. Georgalis - W. Saenger - J. Cryst: Growth 143 (1994) 71-78.

[35] M. Muschol - F. Rosenberger: J. Chem. Phys. 103 (1995) 10424-10432.

[36] M. R. Charies -L. N. Brian - M.L. Abraham: Biophys. J. 70 (1996) 977987.

[37] D. E. Kuehner - C. Heyer - C. Ramsch - U. M. Fornefeld - H. W. Blanch - J. M. Prausnitz: Biophys. J. 73 (1997) 3211-3224.
[38] J. Z. Wu - M. P. John: Fluid Phase Equilibria 155 (1999) 139-154.

[39] S. X. Li - D. Xing - J. F. Li - J. Biol: Phys. 30 (2004) 313-324.

[40] K. Onuma - N. Kanzaki - J. Phys. Chem. B 107 (2003) 11799-11804.

[41] J. I. Rosenfeld - D. T. Wasan - J. Coll: Interface Sci. 47 (1974) 27-31.

[42] W. Humphrey - A. Dalke - K. Schulten - J. Molec: Graphics, 14 (1996) 33-38.

[43] J. C. Phillips - R. Braun - W. Wang - J. Gumbart - E. Tajkhorshid - E. Villa - C. Chipot - R. D. Skeel - L. Kale - K. Schulten - J. Comput: Chem. 26 (2005) 1781-1802.

Nanorészecske-polimer kölcsönhatások új molekuláris megközelítése: alkalmazási példa lizofoszfolipid micella-poliakrilsav rendszerre

A módosítatlan vagy módosított nanorészecskék közötti erốk jobb megértése elônyösen járulhat hozzá olyan új stratégiák kifejlesztéséhez, amelyek egyrészt alkalmasak elöre tervezett tulajdonságú nanorészecske szuszpenzók elôállítására, másrészt ezen anyagok környezeti mozgásának és lebomlásának nyomonkövetésére. A molekula szintú szimulációk, köztük a Molekula Dinamika (MD), nagyban elôsegithetik a kolloid nanorészecskék közötti kölcsönhatások értelmezését. Ugyanakkor e módszerekkel nagyon nagy rendszerek nem modellezhetốk, különleges számítástechnikai háttérigényük, és a számításokhoz szükséges hosszú idô miatt. Közleményünkben egy új, a Merev Testek Dinamikájának (RBD) és a Molekula Dinamikának kombinált ciklusain alapuló számítási módszer alkalmazását mutatjuk be lizofoszfolipid micellákból és poliakrilsavból álló rendszerre. Eredményeink szerint a módszerrel viszonylag gyorsan el lehet jutni a stacionárius kölcsönhatás-szerkezethez. Módszerünk alkalmas lehet környezeti, vagy biológiai szempontból érdekes, legkülönfélébb nanorészecskék kölcsönhatásainak tanulmányozására, egy széles körben használatos és szabadon hozzáférhetô számítógépes program segitségével.

Kulcsszavak: nanorészecske, micella, poliakril sav, lizofoszfolipid micella, merev test dinamika, molekula dinamika

Ref.: http://dx.doi.org//10.14382/epitoanyag-jsbcm.2010.19

Yves Chapron - Alain Porquet - Montserrat Filella: New molecular approach for the simulation of nanoparticle-polymer interactions: application to the system formed by a lysophospholipidic micelle and polyacrylic acid. Építőanyag, 62. évf. 4. szám (2010), 102-107. p.

\section{SZERKESZTŐBIZOTTSÁGI MEGJEGYZÉS}

$A z$ utóbbi két-három évben a korszerű kerámia és szilikát anyagrendszerek területén egyre nagyobb szerephez jut a komplex, szerves és szervetlen anyagokat egyaránt tartalmazó hibridanyagok kutatása és fejlesztése. Ezt jól tükrözi, hogy a 2010. november 14-18. között Oszakában megrendezett 3. Nemzetközi Kerámia Kongresszuson (ICC3) az elôadások számát tekintve a hibrid és nano-szerkezetũ anyagok kutatása területén elért új eredményeket bemutató 5. Szimpózium a harmadik legnépesebb szekciója volt a rendezvénynek. Ettôl több elôadást és posztert Japánban csak a korszerũ elektrotechnikai kerámia szekció (Szimpózium 6.) és az élenjáró mũszaki kerámiák és kompozitok (Szimpózium 14.) tudott felvonultatni. Lapunkban az Yves Chapron, Alain Porquet és Montserrat Filella szerző́k által fentiekben közölt cikkel szeretnénk az elsố lépést megtenni a hibridanyagok kutatása, publikálása felé. Ezek az anyagok gyakran nem csak szerves és szervetlen anyagok szimbiózisából épülnek fel, de olykor egyidejûleg tartalmaznak - vagy tartalmazhatnak - a szilárd kerámia szemcsék és kristályok mellett szerves folyadékokat és/vagy gáz halmazállapotú részecskéket. 